\title{
THE DEPENDENCE SOCIAL ADAPTATION- SOCIALIZATION
}

\author{
Venelin Terziev \\ Academician of the Russian Academy of Natural History, Moscow, Russia, Prof. \\ D.Sc. (Ec.), D.Sc. (National Security), D.Sc. (Social Activities), Ph.D., National Military University, \\ Veliko Tarnovo, Bulgaria; University of Rousse, Rousse, Bulgaria, terziev@skmat.com
}

\begin{abstract}
Dynamic changes in the security environment put military personnel, discharged from service for one reason or another and their families to serious tests. Transiting from military to civilian social medium significantly changes their conditions of life, affecting various aspects of their lives, in the basis of which lie mentality and personality changes of every person, leaving their usual social medium and entering an unfamiliar one. Since research in this field is not so popular, authors of this paper are provoked to explore the factors affecting the mental state of modern Bulgarian servicemen transiting to reserves and their professional adaptation corresponding to the new living conditions and to identify the problem areas of their social and psychological adaptation.
\end{abstract}

Keywords: social adaptation, socialization, adaptation.

\section{INTRODUCTION}

In public space social adaptation is of ten equated to socialization. The grounds for the proponents of this argument lie in the very nature of the social adaptation. Social adaptation, understood as the balance of the individual with the community, could be equated to the socialization, defined by sociology as a process of acquiring the social experience, necessary for the „appointed” by the society social roles of the individual. An individual is considered to be socialized when he is able to participate in coherent action. Socialization refers to those processes through which people learn to effectively participate in social groups. Formally, the abilities of the individual, based on the acquired experience, either in organized or unorganized way, can be perceived as an existing balance between the individual and the social community, and in this sense adaptation and socialization are identical. The possibility of adopting this apparent identity necessarily requires clarification in the interpretation of socialization and social adaptation. This clarification is aimed at detecting the similarities and differences in the content of these concepts.

The difference between the social adaptation and the socialization is "visible" in the state of their complete form. The completed social adaptation is a balance between the social content of the individual and the 
social environment, while the completed (conceptually) socialization is the creation of a possibility (based on lessons learned) for an efficient participation in social life.

Social adaptation and socialization are two separate social phenomena, yet they are complementary in the process of social validation of the individual. The common moments between the observed phenomena occur when they are in the process of their development. The process of socialization - entry into the social environment, adapting to it, performing certain roles and functions - is repeated by each individual, following their predecessors, for the entire history of their formation and development. Mixing in this definition the adaptation with the socialization is not a logical error, but a registration of the common characteristics in the process of development of these two phenomena. For the individual to be able to enter in equilibrium with the social community (to adapt to it), he needs to be filled with social content to the extent tobe able to claim balance with society. In this sense, the process of socialization is also included, it becomes part of the process of social adaptation.

\section{SOCIAL ADAPTATION AS A PROCESS}

Social processes are defined as a series of social phenomena, as a series of changes. Social processes, understood as a series of changes, depending on the system in which they occur, are divided into the following types:

- Intra-personal processes flowing inside the individual;

- Processes flowing in the relationship between two individuals;

- Processes flowing in the relationship between the individual and the group;

- Processes changing the organization and internal structure of society;

- Processes changing the relations between two groups (communities);

- Processes, changing the organizational structure of the global society;

- Processes of mutual rapprochement between people or processes unifying people;

- Processes of alienation or processes dividing people.

The first are associative and to them per tain social accommodation. Understood as the achieving of an equilibrium between the individual and the social community, social accommodation is a "process of mutual rapprochement between people”, an „associative process”. The process of social accommodation contains several necessary elements: "cognitive - understanding the new situation, training in new models and modes of behavior, psychological reorientation".

The mentioned elements of social adaptation reflect in general terms the course of this process and can be attributed to all its varieties. The process of social adaptation does not exist in general, but is concrete lydefined depending on the nature of the communities and the corresponding societies, which are subject to adaptation. The first element is cognitive, or understanding the new situation. This element of social adaptation should be viewed in the general and specific terms of its impact on the process under study.

Adaptation to the community as a whole (particular society) implies knowledge about this society, knowledge related to its general characteristics and patterns of functioning and development. This knowledge implies systematic education, which is implemented in school, university, through the mass media (radio, press, TV, etc.) and by life observation. This aspect of the element of the adaptation process is complemented by its specific form of manifestation. From hisentry in the society till his „exit" from it, the individual participates in many life situations and respectively experiences and refractsthrough himself their impact. Thus he gets to know the social environment to a varying degree adapts to it. The social environment, driven by the objective, attributive toitself laws, is in the process of change, and this change necessarily implies readaptation to the newly created conditions. It is necessary to distinguish between changes in the conditions of social life and the new conditions occurring in it, and this should be done from the point of view of their impact on the adaptation process. The changes in the social life of the individual are related to his adaptation, when they (the changes) are of substantial importance for balancing the individual to the social community. Such significant changes, for example, are the changes in the conditions of economic and political system, the transition of the state of employment to a state of unemployment, etc. From that, it can be seen that it is not only about objective social changes, but also about changes related to the concrete individuals and social groups, i.e. changes inside themselves, and not in general.

From the viewpoint of the first element of the process of social adaptation under study, this type of changes 
is subject of understanding for the adapting individual. Knowing the general characteristics of public life and bringing the significant, the essential for the individual changes in the circumstances of life, in their unity represent the first element of the process of social adaptation.

The second element is the education in new models and modes of behavior. The entry of the individual in various spheres of organized social life presupposes education in new patterns of behavior. Knowledge of certain new conditions by itself does not automatically cause a change in the behavior of the individual to the extent of adequacy with the norms for behavior inherent to one or another organized form of social life, within the various social communities. The education in the new behavior, adequate to the new requirements, is a matter of overcoming old habits, quitting or enrichment by the existing personality of a value orientation and management of personal needs in accordance with new requirements needed to achieve real social adaptation. These mechanisms related to the change of behavior, are often accompanied by the expression of conflicts occurring inside the individual, but also between the individual and the social groups - objects of adaptation.

The term education is used here not in the strictly pedagogical sense. The majority of its content is related to the nature of self-learning, achieved without methodological pedagogical prescriptions. The education into a new behavior, adequate to the new demands of the conditions is a result of the process of sociopsychological communication in which the individual- a subject to adaptation, takes practical participation.

Achieving an appropriate behavior in the conditions of the social environment, subject to adaptation, does not yet complete the process of adaptation. This process can be considered completed with the realization of the psychological reorientation. Third element is the psychological reorientation. The new environment and significant changes in existing social conditions „offer” a not always identical psychological life with the psychological world of the adapting individual. For achieving real adaptation, development of the course of the phenomenon of psychological reorientationis necessary, constituting the third attributive element of the social adaptation as a process.

In the process of participation in the social life the individual builds only an internal psychological position that is relatively independent and is subject to modification and development. Impacts from the outside world, refracted through this psychological position, influence the individual. So the individual separates his independence as a functional unit in a particular social system. The entry of the individual into a new for him social environment includes the psychological perception of this environment, which in essence constitutes a psychological reorientation. This reorientation can be partial (to varying degrees), and complete, to the merging of the psychological position of the individual with the group Psychology. This merging should not be taken as a full identity, but merely as a unity.

The psychological reorientation associated with the process of adaptation is determined by a range of factors that are difficult to identify without examining a particular adaptation process. The preceding analysis (related to the social adaptation as a process) is referred entirely to the adapting individual, the individual - subject to social adaptation. Equal attention should be paid to the object of adaptation, the social environment, regarded as part of the adaptation process. The adaptation to the macro-social community occurs on different levels. In the process of his socialization, the individual is involved in the life of the various formal and informal social groups and through them realizes on an individual level his balance with the macro-social community.

The main problem of the social environment as an object of adaptation is the presence and functioning of the adaptive system in it. The presence of such a system in social groups shows the attention to the problem of social adaptation. The system of social adaptation can be defined as a set of organized social impacts on the individual, seen as a subject of adaptation. For this system to realize itself in action, to start functioning, it is necessary to solve the following groups of problems:

- First- clarification of the basic principles of the system;

- Second- determining the nature, content and consistency in the activities of the system of adaptation impacts;

- Third- development of criteria for measuring the degree of social adaptation;

- Fourth- forecasting the development and improvement of the adaptation system;

- Fifth- solving the issue of human resources (personnel) who should bring in effect the adaptation system.

The basic principles of the adaptation system determine the limits of action and the motives of operation of this system. Functioning of certain principles relates to the operation of the adaptation system in the specific 
conditions. Determining the nature, content and consistency of the activities of the system of adaptation impacts, stem from the principles of functioning of the system in question. To make the social adaptation of the individual to the new manner, possible, it is necessary each specific adaptation system to be implemented in the relevant appropriate manner.

Another, not less important criterion are the personal specifics of the individual, which largely determines the nature, character and manner of presentation of the adaptation impacts, representing the content of the adaptation system. Although the systematic adaptation impacts determine the understanding that the result of their impact is the absorption of the individual by the social environment - object of adaptation, this is only ostensiblyso and is by no means the goal of the adaptation system. Its ultimate goal is to achieve balance with the community, represented by the various and numerous formal and informal groups. Social adaptation of the individual involves the problem of personal development of the individual. In this sense, the adaptation as an organized social process is largely consistent with the individual's personal development.

The nature, content and consistency of the activities of the system of adaptation impacts can be defined as an expression of unity between social requirements and individual freedom in the development of individual skills. The third and fourth group of problems, related to the functioning of the adaptation system are the development of criteria for measuring the degree of social adaptation and forecasting the development and improvement of the system. The latter of the above-mentioned issues, the issue of human resources (personnel) who should bring in effect the adaptation system, has strictly practical significance. So far as social adaptation is a sociological problem, the human resources who implement the adaptation system should be specially trained professionals. But adaptation is also manageable social process, and this circumstance necessarily requires the intervention of specialists in the field of management.

The schematic outline of the problems of the social adaptation system can be seen in two variants:

First- the problem is known and differentiated;

Second - the problems must be clearly defined.

Schematics in the presentation of the problems of the social adaptation system is determined by the second variant. The purpose of this point of the analysis is not solving the problem, but its posing (Terziev, 2018a, pp. 228-236; Stefanov, Terziev, Banabakova, 2018b, pp. 93-102; Stefanov, Terziev, Banabakova, 2018c, pp. 111-119; Terziev, Stefanov, Banabakova, 2018d, pp. 120-131; Terziev, Stefanov, Banabakova, 2018e, pp. 132-148; Terziev, 2018f, pp. 213-227; Terziev, 2018g, pp. 237-247; Terziev, 2018h, pp. 256-265; Terziev, 2018i, pp. 266-276; Terziev, Latyshev, Georgiev, 2018j, pp. 248-255; Glushkov, Simeonov, Georgiev, 2018k, pp. 88-92).

\section{FACTORS FOR SOCIAL ADAPTATION}

Social adaptation happens in the interaction between factors of the individual and factors of the external (social) environment. The activity of the individual in the adaptation process becomes possible within a completed socialization, when the individual has a relatively developed social structure, through which he refracts the effects of the social environment. This circumstance makes the adaptation process complex and multidirectional. On the basis of an established social structure, a system of factors of social adaptation can be discussed.

The factors for social adaptation can be addressed in two main groups. The first group comprises the factors of the individual:

- Psychological content;

- Moral content;

- Political content;

- Cultural content;

- Intellectual content.

These factors of the individual are elements of his social structure. They affect only with a certain power the process of social adaptation, and as a whole and as a system among the mselves, they represent the social value of the individual. The second group comprises the factors of the social environment:

- Organized upbringing;

- Education; media; 
- Public opinion;

- Social events.

The social environment, as anobject of adaptation, is of critical importance for the flow of the adaptation process. All its possible effects on the individual are in one or another way related to the adaptation process.

Following the logic of our reasoning, our research is further aimed at the social adaptation of the military servicemen, which in the years of reforms, reduction, lay-offs in the structures of the military forces and the Bulgarian Army, gained wide popularity.

Social adaptation of the servicemen and the members of their families in today's conditions is a process and form of reconciliation of the individual with the world, resolving the contradiction between certain personality type (the discharged from military service serviceman and his family) and a certain type of social environment (new socio-economic conditions and transition to a new occupational activity) (Banabakova, Georgiev, 2017a, pp. 37-47; Banabakova, Georgiev, 2018l, pp. 462-467; Terziev, 2017b, pp.517-528; Terziev, 2017c; Hristov, 2018m, pp. 277-282; Terziev, Nichev, 2017d, p.152; Terziev, Nichev, 2017e, pp.846-850; Terziev, Nichev, 2017f, p.164; Terziev, Nichev, 2017g, pp.915-919; Terziev, Madanski, Georgiev, 2017h, pp.743-747; Terziev, Madanski, Georgiev, 2017i, pp.748-753; Terziev, Nichev, Stoyanov, Georgiev, 2017j, pp.690-694; Terziev, Latyshev, Georgiev, 2017k, pp.754-772; Terziev, Nikolay, Bogdanov, 2017l, pp.671-677; Terziev, Madanski, Kanev, 2017m, pp.1331-1346; Terziev, Madanski, Kanev, 2017n, pp.1355-1372; Terziev, Madanski, Kanev, 2017o, pp.1380-1393; Terziev, Madanski, Kanev, 2017p, pp.396415; Terziev, 2017q, pp.641-653; Terziev, Nichev, 2017r, pp.627-630; Terziev, Madanski, Kanev, 2017s, pp.575-594; Terziev, 2017t, pp.22-28; Terziev, Nichev, 2017u, pp.646-658; Terziev, Nichev, 2017v, pp.659670; Terziev, Madanski, 2017w, pp.610-625; Terziev, Madanski, 2017x, pp.917-937).

\section{REFERENCE LIST}

Terziev, Venelin. (2018a). Building a model of social and pshychological adaptation. // ADVED 2018- 4th International Conference on Advances in Education and Social Sciences Abstracts \& Proceedings, 1517 October 2018- Istanbul, Turkey, International Organization Center of Academic Research, www.ocerints.org, Istanbul, Turkey, 2018, pp. 228-236, ISBN: 978-605-82433-4-7.

Stefanov, S., Terziev, V., Banabakova, V. (2018b). The undertsanding of security in the postmodern society. // ADVED 2018- 4th International Conference on Advances in Education and Social Sciences Abstracts \& Proceedings, 15-17 October 2018- Istanbul, Turkey, International Organization Center of Academic Research, www.ocerints.org, Istanbul, Turkey, 2018, pp. 93-102, ISBN: 978-605-82433-4-7.

Stefanov, S., Terziev, V., Banabakova, V. (2018c). Levels of security and postmodern society. // ADVED 2018- 4th International Conference on Advances in Education and Social Sciences Abstracts \& Proceedings, 15-17 October 2018- Istanbul, Turkey, International Organization Center of Academic Research, www.ocerints.org, Istanbul, Turkey, 2018, pp. 111-119, ISBN: 978-605-82433-4-7.

Terziev, V., Stefanov, S., Banabakova, V. (2018d). Implementattion of the common european security and defence policy in the context of its military aspect. // ADVED 2018- 4th International Conference on Advances in Education and Social Sciences Abstracts \& Proceedings, 15-17 October 2018- Istanbul, Turkey, International Organization Center of Academic Research, www.ocerints.org, Istanbul, Turkey, 2018, pp. 120-131, ISBN: 978-605-82433-4-7.

Terziev, V., Stefanov, S., Banabakova, V. (2018e). Common european security and defence policy. // ADVED 2018- 4th International Conference on Advances in Education and Social Sciences Abstracts \& Proceedings, 15-17 October 2018- Istanbul, Turkey, International Organization Center of Academic Research, www.ocerints.org, Istanbul, Turkey, 2018, pp. 132-148, ISBN: 978-605-82433-4-7.

Terziev, Venelin. (2018f). Bulgarian experience in the development of social adaptation of military personnel, discharged from military service and their families. // ADVED 2018- 4th International Conference on Advances in Education and Social Sciences Abstracts \& Proceedings, 15-17 October 2018- Istanbul, Turkey, International Organization Center of Academic Research, www.ocerints.org, Istanbul, Turkey, 2018, pp. 213-227, ISBN: 978-605-82433-4-7.

Terziev, Venelin. (2018g). Opportunities of aplication of a competence-based approach in social adaptation 
of militaries discharged of service. // ADVED 2018- 4th International Conference on Advances in Education and Social Sciences Abstracts \& Proceedings, 15-17 October 2018- Istanbul, Turkey, International Organization Center of Academic Research, www.ocerints.org, Istanbul, Turkey, 2018, pp. 237-247, ISBN: 978-605-82433-4-7.

Terziev, Venelin. (2018h). Possible aspects of occupational and psychological adaptation of the military, discharged from military service and their families to a new activity life cycle. // ADVED 2018- 4th International Conference on Advances in Education and Social Sciences Abstracts \& Proceedings, 1517 October 2018- Istanbul, Turkey, International Organization Center of Academic Research, www.ocerints.org, Istanbul, Turkey, 2018, pp. 256-265, ISBN: 978-605-82433-4-7.

Terziev, Venelin. (2018i). Realities of implementing the social adaptation process of military personnel, discharged form service in Bulgaria. // ADVED 2018- 4th International Conference on Advances in Education and Social Sciences Abstracts \& Proceedings, 15-17 October 2018- Istanbul, Turkey, International Organization Center of Academic Research, www.ocerints.org, Istanbul, Turkey, 2018, pp. 266-276, ISBN: 978-605-82433-4-7.

Terziev, V., Latyshev, O., Georgiev, M. (2018j). The warehousing as an element of army logistics system in conditions of arctics (from experience of bulgarianrussian cooperation). // ADVED 2018- 4th International Conference on Advances in Education and Social Sciences Abstracts \& Proceedings, 1517 October 2018- Istanbul, Turkey, International Organization Center of Academic Research, www.ocerints.org, Istanbul, Turkey, 2018, pp. 248-255, ISBN: 978-605-82433-4-7.

Glushkov, P., Simeonov, S., Georgiev, M. (2018k). Method of determination of the diurnal energy consumption of the cadets from the Vasil Levski National Military university. ADVED 2018- 4th International Conference on Advances in Education and Social Sciences Abstracts \& Proceedings, 1517 October 2018- Istanbul, Turkey, International Organization Center of Academic Research, www.ocerints.org, Istanbul, Turkey, 2018, pp. 88-92, ISBN: 978-605-82433-4-7.

Banabakova, V., Georgiev, M. (2017a). Problems and perspectives in Military professional education and realization of cadets in Bulgaria. // Journal of Innovations and Sustainability, Innovations and Sustainability Academy. 3, 2017, N 4, pp. 37-47, ISSN 2367-8127 (CD-ROM), ISSN 2367-8151 (online).

Banabakova, V., Georgiev, M. (2018I). Military professional forming of the cadets at Vasil Levski National Military University. // Proceedings of INTCESS2018- 5th International Conference on Education and Social Sciences 5-7 February 2018- Istanbul, Turkey, International Organization Center of Academic Research, www.ocerints.org, Istanbul, Turkey, 2018, pp. 462-467, ISBN : 978-605-82433-2-3.

Terziev, Venelin. (2017b). Opportunities and trends in the development and the improvement processes in the Bulgarian military educational system. // 3rd Central \& Eastern European LUMEN International Conference, New Approaches in Social and Humanistic Sciences NASHS 2017, Chisinau, Republic of Moldova, June 8-10, 2017, 2018, pp.517-528, ISSN (print): 2601 - 2510, ISSN (on-line): 2601 2529, ISSN-L: 2601 - 2510, ISBN: 978-1-910129-15-9.

Terziev, Venelin. (2017c). Opportunities for improving the efficiencyof the socialadaptation of servicemen discharged from military service in Bulgaria. // Catalogue of the scientific, educational and methodical literature presented by authors at the I-XXXIV All-Russian book exhibitions held by Academy of Natural History, Exposition on the Frankfurter Buchmesse 2017, XXVII, Moskow, Academy of Natural History, 2017.

Hristov, Neno. (2018m). European intervention initiative vs common European army. ADVED 2018- 4th International Conference on Advances in Education and Social Sciences Abstracts \& Proceedings, 1517 October 2018- Istanbul, Turkey, International Organization Center of Academic Research, www.ocerints.org, Istanbul, Turkey, 2018, pp. 277-282, ISBN: 978-605-82433-4-7.

Terziev, V., Nichev, N. (2017d). Research on the management skills and abilities acquired in the military education system. // CBU International Conference Book of Abstracts March 22-24, Prague, Czech Republic, Innovations in Science and Education, 2017, ISBN 978-80-88042-09-9, p.152.

Terziev, V., Nichev, N. (2017e). Research on the management skills and abilities acquired in the military education system. // CBU International Conference Proceedings 2017, March 22-24, Prague, Czech Republic, Innovations in Science and Education, 2017, SSN 1805-997X (Print), ISBN 978-80-8804207-5 (Print edition), pp.846-850.

Terziev, V., Nichev, N. (2017f). Developing the readiness for the organizational activity of the cadets. // CBU 
International Conference Book of Abstracts March 22-24, Prague, Czech Republic, Innovations in Science and Education, ISBN 978-80-88042-09-9, p.164.

Terziev, V., Nichev, N. (2017g). Developing the readiness for the organizational activity of the cadets. // CBU International Conference Proceedings 2017, March 22-24, Prague, Czech Republic, Innovations in Science and Education, 2017, SSN 1805-997X (Print), ISBN 978-80-88042-07-5 (Print edition), pp.915-919.

Terziev, V., Madanski, V., Georgiev, M. (2017h). Offset implementation impact on technology transfer in Bulgaria. // Proceedings of ADVED 2017- 3rd International Conference on Advances in Education and Social Sciences 9-11 October 2017- Istanbul, Turkey, 2017, ISBN: 978-605-82433-0-9, pp.743-747.

Terziev, V., Madanski, V., Georgiev, M. (2017i). Offset as an economic operation and a trade practice. // Proceedings of ADVED 2017- 3rd International Conference on Advances in Education and Social Sciences 9-11 October 2017- Istanbul, Turkey, 2017, ISBN: 978-605-82433-0-9, pp.748-753.

Terziev, V., Nichev, N., Stoyanov, E., Georgiev, M. (2017j). A general principle of the development process of balanced scorecards as an instrument of control. // Proceedings of ADVED 2017- 3rd International Conference on Advances in Education and Social Sciences 9-11 October 2017- Istanbul, Turkey, 2017, ISBN: 978-605-82433-0-9, pp.690-694.

Terziev, V., Latyshev, O., Georgiev, M. (2017k). Building competencies for social work through continuing vocational training. // Proceedings of ADVED 2017- 3rd International Conference on Advances in Education and Social Sciences 9-11 October 2017- Istanbul, Turkey, 2017, ISBN: 978-605-82433-0-9, pp.754-772.

Terziev, V., Nikolay, N., Bogdanov, P. (2017l). Comparative analysis of the formation of military professional skills in the cadets to be trained in logistics specializations. // Proceedings of ADVED 2017-3rd International Conference on Advances in Education and Social Sciences 9-11 October 2017- Istanbul, Turkey, 2017, ISBN: 978-605-82433-0-9, pp.671-677.

Terziev, V., Madanski, V. Kanev, D. (2017m). Entry opportunities in the Bulgarian military-educational system. // Sport, Education and Society, Taylor \& Francis, 22, 2017, N 8(2), Source Normalized Impact per Paper (SNIP): 1.459 SCImago Journal Rank (SJR): 1.005 Impact factor: 1.269 Ranking: 60/230 (Education \& Educational Research), 20/44 (Hospitality, Leisure, Sport and Tourism), 51/82 (Sport Sciences), Print ISSN: 1357-3322 Online ISSN: 1470-1243, pp.1331-1346.

Terziev, V., Madanski, V., Kanev, D. (2017n). Condition and capabilities of the military-educational system of the Republic of Bulgaria. // Sport, Education and Society, Taylor \& Francis, 22, 2017, N 8(2), Source Normalized Impact per Paper (SNIP): 1.459 SCImago Journal Rank (SJR): 1.005 Impact factor: 1.269 Ranking: 60/230 (Education \& Educational Research), 20/44 (Hospitality, Leisure, Sport and Tourism), 51/82 (Sport Sciences), Print ISSN: 1357-3322 Online ISSN: 1470-1243, pp.1355-1372.

Terziev, V., Madanski, V., Kanev, D. (20170). Directions for improvement of the military-educational system and its contribution for strengthening national security and the defence of the country. // Sport, Education and Society, Taylor \& Francis, 22, 2017, N 8(2), Source Normalized Impact per Paper (SNIP): 1.459 SCImago Journal Rank (SJR): 1.005 Impact factor: 1.269 Ranking: 60/230 (Education \& Educational Research), 20/44 (Hospitality, Leisure, Sport and Tourism), 51/82 (Sport Sciences), Print ISSN: 1357-3322 Online ISSN: 1470-1243, pp.1380-1393.

Terziev, V., Madanski, V., Kanev, D. (2017p). Entry opportunities in the bulgarian military-educational system and ensuring of civil rights. // IJAEDU- International E-Journal of Advances in Education, 3, 2017, N 8 , e-ISSN:2411-1821, pp.396-415.

Terziev, Venelin. (2017q). The needs of continuing vocational training of social work specialists providing social services. // Proceedings of SOCIOINT 2017- 4th International Conference on Education, Social Sciences and Humanities 10-12 July 2017- Dubai, UAE, 2017, ISBN: 978-605-82433-1-6, pp.641-653.

Terziev, V., Nichev, N. (2017r). Analysis of the environment for military educational system functioning and its impact on the preparation of cadets for military professional activities in the republic of Bulgaria. // Proceedings of SOCIOINT 2017- 4th International Conference on Education, Social Sciences and Humanities 10-12 July 2017- Dubai, UAE, 2017, ISBN: 978-605-82433-1-6, pp.627-630.

Terziev, V., Madanski, V., Kanev, D. (2017s). Entry opportunities in the bulgarian military-educational system and ensuring of civil rights. // Proceedings of SOCIOINT 2017- 4th International Conference on Education, Social Sciences and Humanities 10-12 July 2017- Dubai, UAE, 2017, ISBN: 978-605- 
82433-1-6, pp.575-594.

Terziev, Venelin. (2017t). National security of the republic of Bulgaria. // International Journal of Management and Applied Science, 3, 2017, N 4, ISSN: 2394-7926, pp.22-28.

Terziev, V., Nichev, N. (2017u). Research of the value orientation and structural peculiarities of management activitiesofcadets in the course of military professional training. // Proceedings of the VII International Academic Congress „Fundamental and Applied Studies in EU and CIS Countries” (United Kingdom, Cambridge, England, 26-28 February 2017), Cambridge University Press, 7, 2017, ISBN: 978-0-87583597-4, pp.646-658, Source Normalized Impact per Paper (SNIP): 5.192 SCImago Journal Rank (SJR): 5.186 Impact factor: 7.549 .

Terziev, V., Nichev, N. (2017v). Research of the motivation for management activities of cadets in the course of their military professional training. // Proceedings of the VII International Academic Congress „Fundamental and Applied Studies in EU and CIS Countries” (United Kingdom, Cambridge, England, 26-28 February 2017), Cambridge University Press, 7, 2017, ISBN: 978-0-875-83597-4, pp.659-670, Source Normalized Impact per Paper (SNIP): 5.192 SCImago Journal Rank (SJR): 5.186 Impact factor: 7.549 .

Terziev, V., Madanski, V. (2017w). Guidelines for development of military education system in Bulgaria. // Proceedings of the VII International Academic Congress "Fundamental and Applied Studies in EU and CIS Countries" (United Kingdom, Cambridge, England, 26-28 February 2017), Cambridge University Press, ISBN: 978-0-875-83597-4, 7, 2017, pp.610-625, Source Normalized Impact per Paper (SNIP): 5.192 SCImago Journal Rank (SJR): 5.186 Impact factor: 7.549.

Terziev, V., Madanski, V. (2017x). Development of military education system in Bulgaria. // American Journal of Education, The University of Chicago Press, 2017, 123, 2017, N 4 (2), ISSN: 0195-6744, pp.917937, Source Normalized Impact per Paper (SNIP): 1.653, SCImago Journal Rank (SJR): 2.243. 